\title{
Effect of Modified Dry Period Lengths and Bovine Somatotropin on Yield and Composition of Milk from Dairy Cows
}

\author{
E. L. Annen, ${ }^{1}$ R. J. Collier, ${ }^{1}$ M. A. McGuire, ${ }^{2}$ J. L. Vicini, ${ }^{3}$ \\ J. M. Ballam, ${ }^{3}$ and M. J. Lormore ${ }^{3}$ \\ ${ }^{1}$ Department of Animal Science, \\ University of Arizona, Tucson 85721 \\ ${ }^{2}$ Department of Animal and Veterinary Science, \\ University of Idaho, Moscow 83844 \\ ${ }^{3}$ Animal Agriculture Business, Monsanto Company, \\ St. Louis, MO 63198
}

\section{ABSTRACT}

Dry periods of 40 to $60 \mathrm{~d}$ have been an industry standard because dry periods $<40 \mathrm{~d}$ have resulted in reduced milk yields in the subsequent lactation by 10 to $30 \%$. However, recent research has demonstrated no production losses for cows given a 30-d dry period. The current study evaluated milk production effects of shortened or omitted dry periods for cows at mature-equivalent production $>12,000 \mathrm{~kg}$ of milk and treated with bovine somatotropin (bST). The study used 2 commercial dairies and one university dairy and included 4 treatments. Five multiparous and 5 primiparous cows from each farm were assigned to each treatment: 1) 60-d dry period, label use of bST (60DD); 2) 30-d dry period, label use of bST (30DD); 3) continuous milking, label use of bST (CMLST); and 4) continuous milking with continuous use of bST (CMCST). Per label, bST use started at 57 to $70 \mathrm{~d}$ in milk and ended $14 \mathrm{~d}$ before drying (60DD and 30DD) or expected calving date (CMLST). In primiparous cows, average milk yields during the first 17 wk of lactation were reduced for cows on treatments 30DD, CMLST, and CMCST vs. the 60DD treatment. (38.3, 35.1 , and 37.5 vs. $44.1 \pm 1.3 \mathrm{~kg} / \mathrm{d}$, respectively). For multiparous cows, respective milk yields did not differ $(46.6,43.4,46.5$, and $47.7 \pm 2.1 \mathrm{~kg} / \mathrm{d})$. Shortened or omitted dry periods may impede mammary growth in primiparous cows, resulting in reduced milk yield in the subsequent lactation. In contrast, a shortened or omitted dry period with either bST protocol did not alter production in multiparous cows treated with bST. Quality aspects of prepartum milk and colostrum require additional characterization. For multiparous cows, milk income generated for short dry periods or for continuous milking might increase their profitabil-

Received January 13, 2004.

Accepted June 23, 2004.

Corresponding author: R. J. Collier; e-mail: rcollier@ag. arizona.edu. ity. At 17 wk of the subsequent lactation, estimates of the cumulative net margins of multiparous cows on the 30DD treatment and continuous milking treatments exceeded those of cows on the 60DD treatment by $\$ 40$ to $\$ 60$ per cow.

(Key words: continuous lactation, shortened dry period, bovine somatotropin)

Abbreviation key: 30DD = 30-d dry period, label use of bST; 60DD = 60-d dry period, label use of bST; CM = continuous milking; CMCST = no dry period, continuous use of bST; CMLST = no dry period, label use of bST; $\mathbf{C N M}=$ cumulative net margin; $\mathbf{M E C}=$ mammary epithelial cell; RIA = radioimmunoassay; $\mathbf{W R C}$ = week relative to calving.

\section{INTRODUCTION}

Research evaluating the dry period requirement in dairy cows suggests that a 2-mo dry period is optimal and that a dry period $<40 \mathrm{~d}$ results in reduced milk yields in the succeeding lactation (Klein and Woodward, 1943; Wilton et al., 1967; Schaeffer and Henderson, 1972; Coppock et al., 1974; Funk et al., 1987; Sørensen and Enevoldsen, 1991). However, much of those data were derived from retrospective analyses of dairy records rather than planned experiments. In other studies, a 30-d dry period did not affect milk production in the next lactation (Lotan and Alder, 1976; Bachman, 2002; Bachman and Schairer, 2003; Gulay et al., 2003; Rastani et al., 2003). Complete omission of the dry period in controlled studies resulted in 17 to $38 \%$ reductions in milk yield in the subsequent lactation (Swanson, 1965; Smith et al., 1967; Rémond et al., 1992).

Four hypotheses have been proposed to explain reduced milk yields in continuously milked (CM) cows: 1) inadequate body reserves (Swanson, 1965), 2) endocrine differences (Smith et al., 1967), 3) reduced mammary epithelial cell numbers (Swanson et al., 1967; Capuco et al., 1997), and 4) reduced mammary functionality, 
i.e., reduced secretory and/or mitotic capacity (Swanson et al., 1967; Capuco et al., 1997). Using identical twins, Swanson (1965) refuted the nutritional hypothesis by demonstrating that CM twins maintained heavier BW throughout the study, but milk yield was reduced by $25 \%$ in the second lactation and $38 \%$ in the third lactation. If nutrition limited milk yield, higher rather than reduced milk yield in CM cows would be expected based on BW differences. Smith et al. (1967), using a halfudder model to evaluate milk production in $\mathrm{CM}$ and control (60-d dry) quarters, observed reduced milk yield in CM glands, even though supply of nutrients and endocrine factors were equal for all quarters. Autocrineand paracrine-acting hormonal factors may play a role in reduced milk yield in CM glands, but these have not been investigated. A reduction in total mammary cell numbers in CM quarters or cows has not been demonstrated in cattle (Swanson et al., 1967; Capuco et al., 1997), but has been shown in rats (Paape and Tucker, 1969) and suggested in goats (Fowler et al., 1991). Reduced mammary epithelial cell (MEC) functionality in CM cows was suggested by Swanson et al. (1967) because mammary DNA content and alveolar concentrations were not affected by a 6 -wk difference in dry period length. Capuco et al. (1997) also found no differences in mammary DNA content in CM cows compared with 60-d dry cows, but MEC proliferation was reduced by $80 \%$ in CM cows. Reduced proliferation but equal DNA content may occur in CM cows that have reduced MEC turnover but carry more senescent mammary cells into the subsequent lactation (Capuco et al., 1997). Increased MEC carryover from one lactation to the next has been demonstrated in CM rats (Pitkow et al., 1972). An older population of MEC may be the causative factor of reduced mammary functionality and milk yields in CM cows or glands. This assumes that older MEC have reduced proliferative and secretory capacity (Capuco and Akers, 1999).

Much of the data on shortened or omitted dry periods has been generated using cows reaching peak milk yields of 20 to $30 \mathrm{~kg} / \mathrm{d}$, compared with today's highproducing cows, which are capable of peak milk yields in excess of $50 \mathrm{~kg} / \mathrm{d}$. Moreover, improved milk production levels and lactation persistency have resulted in higher milk yields at drying. Cows producing $>30 \mathrm{~kg} / \mathrm{d}$ at drying have potential to milk through the last $60 \mathrm{~d}$ of gestation at a profitable production level. In addition to production increases, there are many new dairy management strategies and galactopoietics (increased milking frequency, photoperiod management, and bST) that may impact mammary functionality in $\mathrm{CM}$ cows but have not been investigated. The effects of bST on CM cows is especially interesting because bST increases milk yield by 10 to $15 \%$ and impacts MEC by improving synthetic capacity, reducing the number of resting MEC, and/or reducing MEC loss (Bauman and Vernon, 1993). A 30-d dry period has been evaluated in highproducing cows in conjunction with a low dose of bST administered throughout gestation and early lactation (Gulay et al., 2003, 2004). No loss or gain in subsequent milk production was detected for 30- or 60-d dry cows, regardless of bST treatment. However, as a main effect, bST-treated cows had higher milk yield through the first 10 wk of lactation (Gulay et al., 2004). We hypothesized that a shortened or omitted dry period in bSTsupplemented, high-producing cows would have negligible effects on milk production in the subsequent lactation.

Therefore, the objectives of the following study were 1) to determine effects of a shortened or omitted dry period with label use of bST and of an omitted dry period and continuous use of bST on subsequent milk yield and composition and 2) to determine economic returns of a shortened or omitted dry period in primiparous and multiparous cows.

\section{MATERIALS AND METHODS}

University of Arizona and University of Idaho Institutional Animal Care and Use Committees approved all procedures involving animals. The study used 3 herds: 2 Idaho dairies (herds 1 and 2) and one Arizona dairy (herd 3). All cows had ad libitum access to feed and water. herds 1 and 2 were milked 3 times/d, and herd 3 was milked 2 times/d. At each milking, yield was determined by milk meters and recorded in Dairy Comp 305 (DC305; Valley Ag Software, Visalia, CA) and was stored for $7 \mathrm{~d}$. Weekly backup files were retrieved, and milk yield data were transferred to an Excel (Microsoft Corp., Redmond, WA) spreadsheet. Milk samples from one milking were taken monthly and analyzed for fat percentage, true protein percentage, and SCC (herd 1Treasure Valley Milk Testing, Meridian, ID; herd 2Northwest Laboratories, Jerome, ID; herd 3-Arizona Dairy Herd Improvement Association, Tempe, AZ). Milk fat and protein were analyzed using AOAC-approved infrared analyses. Analysis for SCC was done using AOAC-approved cell staining techniques. All equipment used in the analyses was certified by the International Dairy Federation and the FDA. Daily milk production data and monthly milk composition data were collected for the last $17 \mathrm{wk}$ of gestation and the first 17 wk of the subsequent lactation. Daily milk yield data from each cow were collapsed into weekly means of daily milk yield for statistical analyses.

From each herd, 40 pregnant, lactating cows were selected for the study. Herds 1 and 2 used all Holstein cows on the study. Herd 3 used both Holstein and Brown 
Swiss cows. Treatment groups in herd 3 were balanced for breed. Selection criteria for cows during the initial lactation on the study were 1) 305-d mature-equivalent milk production $>12,000 \mathrm{~kg}, 2)$ supplementation with bST (POSILAC; Monsanto Company, St. Louis, MO) according to label (begin supplementation at 57 to 70 DIM), and 3) SCC $<200,000$. Within each herd, study cows were selected from the group of cows meeting the aforementioned criteria and assigned randomly to treatment. The study included 4 treatments: 1) 60-d dry period, label bST supplementation (60DD); 2) 30d dry period, label use of bST (30DD); 3) no dry period, label use of bST (CMLST); and 4) no dry period, continuous bST supplementation (CMCST). The bST product used was a sustained-release formulation that delivered $500 \mathrm{mg}$ of recombinant bST over a 14-d interval. Label use requires injections every $14 \mathrm{~d}$ starting at 57 to 70 DIM and discontinue at the end of lactation. In the current study, bST injections were given at 14-d intervals on a set day of the week. Therefore, 60DD and 30DD cows received their last injection 27 to 14 $\mathrm{d}$ before drying, and CMLST cows received their last injection 27 to $1 \mathrm{~d}$ before actual parturition. Differences between expected and actual parturition dates resulted in a greater range of days for last bST injection for CMLST cows. Postpartum injections of bST were initiated at $\mathrm{d} 57$ to 70 in 60DD, 30DD, and CMLST cows. The CMCST cows received their last prepartum injection of bST 1 to $14 \mathrm{~d}$ before parturition. Injections continued into the next lactation on the same 14-d interval used prepartum, making the first postpartum injection between $d 1$ and 13. The study was conducted under an FDA Investigational New Animal Drug permit because supplementing bST from parturition to 57 DIM is offlabel use of POSILAC. Each treatment contained 5 primiparous cows and 5 multiparous cows from each herd. Primiparous cows were in their first lactation at the start of the study, and multiparous cows were in their second or greater lactation at the start of the study.

\section{Drying Protocols}

Cows were dried by abrupt cessation of milking and were administered intramammary antibiotics designated for use in dry cows. Cows assigned to no dry period (CMLST and CMCST) were considered to be drying spontaneously when, unrelated to illness, their production dropped below a level preset by each of the herds for 7 consecutive days. Herds 2 and 3 dried cows producing $<9 \mathrm{~kg} / \mathrm{d}$, and herd 1 dried cows producing $<14 \mathrm{~kg} / \mathrm{d}$. The production levels for spontaneous drying for all cows were set by each herd based on their breakeven production level. Cows from CMLST and CMCST were dried according to the procedures used for 60DD and 30DD, except that intramammary antibiotics used had shorter withdrawal times. After parturition, withdrawal times were followed, all cows were tested for antibiotic residues in milk, and milk was discarded until tested antibiotic free.

\section{Cow Movement and Ration Changes}

All cows were fed a TMR formulated to meet or exceed nutrient requirements for their given production level and/or stage of gestation. Cows assigned to 60DD and 30DD were fed a lactating ration until milk stasis. At the time of milk stasis, they were moved to a far-off dry cow pen and fed a far-off dry cow ration until $21 \mathrm{~d}$ before their expected parturition date. Cows were then moved to the close-up dry cow pen and fed a close-up ration. At parturition, they were moved into lactating cow pens and fed a lactating ration. Cows assigned to CMLST and CMCST were fed a lactating ration throughout the study, unless they were dried because of low production. Cows dried $<21 \mathrm{~d}$ before their expected parturition date were moved to the close-up dry cow pen and fed a close-up ration. At parturition, they were moved into lactating cow pens and fed a lactating ration. Cows assigned to CM treatments that were actually dry $>21 \mathrm{~d}$ were removed from the study because the primary objective was to examine the biology of omitted dry periods or very short dry periods on subsequent milk yield. Cows assigned to 30DD that were dried because of low production for $>50 \mathrm{~d}$ were also removed from the study.

\section{Colostrum Sampling and Analysis}

Colostrum samples were collected for herds 2 and 3 . To prevent calves from nursing the dam, herd 2 calves were removed from the dam within 20 min of parturition and fed colostrum, and herd 3 calves were fed 3.8 $\mathrm{L}$ of colostrum at parturition, but remained with the dam until fetal membranes were passed or for $12 \mathrm{~h}$ after parturition. Colostrum samples were collected for the first 4 milkings after parturition and analyzed for IgG content. Because of labeling errors, the milking number relative to parturition could not be accurately determined for herd 2. However, samples were identified by cow, and it was known that each of those samples was from 1 of the first 4 milkings after parturition. Within herd 3, samples were labeled correctly, and IgG content for each of the first 4 milkings postpartum was determined. Data from herd 3 and from the literature indicated higher IgG levels in first-milking colostrum relative to subsequent milkings. Therefore, the highest IgG value from the 4 samples analyzed for each cow from herd 2 was designated as the presumptive first- 
milking colostrum value. This presumptive first-milking IgG value and known first-milking IgG values from herd 3 were used for statistical analyses. Colostrum IgG values were determined by radioimmunoassay (RIA). Assay procedures are described by Richards et al. (1999) with modifications by Duff et al. (2000). Prior to assay, samples were diluted 1:2000 in assay buffer. All samples were analyzed within the same assay. The intraassay coefficient of variation was $6.9 \%$.

\section{Statistical Analysis}

All statistical analyses were performed using Proc Mixed procedures in SAS (v.8.2; SAS, 1999). The level of significance was set at $P<0.05$ for main effects and interactions. Data collected from 17 to $12 \mathrm{wk}$ prepartum were used for the covariate in all analyses except colostrum IgG content. During this period, all treatment protocols were identical, and any production differences among treatment groups were unrelated to the current study. Milk yield and composition data from primiparous and multiparous cows were analyzed separately. Weekly milk yield analysis included prepartum milk from the last $8 \mathrm{wk}$ of gestation and postpartum milk yield from 2 to $17 \mathrm{wk}$ postpartum. During the last 8 wk of gestation, zero was entered for any week in which a cow was nonlactating, regardless of treatment. The first week postpartum was omitted from the analysis because of missing data. Independent variables in the model were treatment, week relative to calving (WRC), herd, breed, covariate, and their potential interactions. Total milk yield measures (total milk produced during the last 8 wk of gestation, total milk produced during wk 2 to 17 postpartum, and total milk produced during the last 8 wk of gestation and first 2 to 17 wk postpartum) were also analyzed. The independent variables for total milk analysis were treatment, herd, breed, treatment $\times$ herd, treatment $\times$ breed, and herd $\times$ breed. The dependent variables in the milk composition analysis were milk fat percentage, milk protein percentage, and SCS. Independent variables in the model were treatment, month relative to calving, herd, breed, covariate, and their potential interactions. One analysis of IgG content in first-milking colostrum used IgG concentration from the first milking (herd 3) and presumptive first milking (herd 2) as the dependent variable and treatment group as the independent variable. Within herd 3, IgG analyses used treatment, breed, and milking number relative to parturition as independent variables. For all analyses except total milk measures and IgG from first milkings, WRC, month relative to calving, or milking number was fit as a repeated measure using a first-order autoregressive covariance structure. The covariance parameters were fit separately by breed because of heterogeneity between breeds. The variability among cows within experiment cells was used to test the whole-plot effects of herd, breed, treatment, and their interactions. The variability among milk yield and composition data within cows was used to test for the effects of WRC, month relative to calving, or milking number and interactions involving these variables. For all total milk variables and IgG content, the error term was the residual variance or the variability among cows within experiment cells. For all analyses except herd $3 \mathrm{IgG}$, breed was nested within herd because only one herd had 2 breeds.

\section{Economic Analysis}

Because the timing of cash flow is especially important in assessing when benefits and losses may occur with respect to parturition, a net margin or net benefit (loss) was calculated for each week of the study using standard partial budgeting procedures. As time proceeded, this net margin was cumulated into what has been expressed as cumulative net margin (CNM). In all cases, the 60DD group was used as the control group, and all margins were calculated relative to their performance. No attempt was made to account for additional changes in labor or grouping costs, nor was any risk differential considered for any possible health benefits or losses as has been proposed by Annen et al. (2004).

The following equation was used to calculate the CNM for 30DD, CMLST, and CMCST groups:

$$
\mathrm{CNM}=\sum_{j}^{i}(\text { milk revenue }-(\text { feed costs }+ \text { bST costs }))
$$

where $i, j=\mathrm{wk}-8$ to +17 .

Assumptions used for these calculations were: BW = 567 or $658 \mathrm{~kg}$ (primiparous or multiparous), milk price $=$ $\$ 10.00 / \mathrm{cwt}$, lactating ration cost $=\$ 0.176 / \mathrm{kg} \mathrm{DM}$, dry cow rations cost $=\$ 0.132 / \mathrm{kg} \mathrm{DM}$, and bST cost $=\$ 5.25 /$ $14 \mathrm{~d}$. Dry matter intake estimations were calculated based on BW and production levels. Weekly means from Figure 1 were used for CNM calculations.

\section{RESULTS AND DISCUSSION}

The dry period requirement was investigated in highproducing, bST-supplemented cows that were subjected to a control (60DD), shortened (30DD), or omitted dry period with label (CMLST) or continuous bST supplementation (CMCST). The objectives of the dry period lengths in 60DD and 30DD treatments were met by average days dry of 55 and $30 \mathrm{~d}$, respectively, in primiparous cows and average days dry of 63 and $32 \mathrm{~d}$, respectively, in multiparous cows (Table 1). In primiparous 

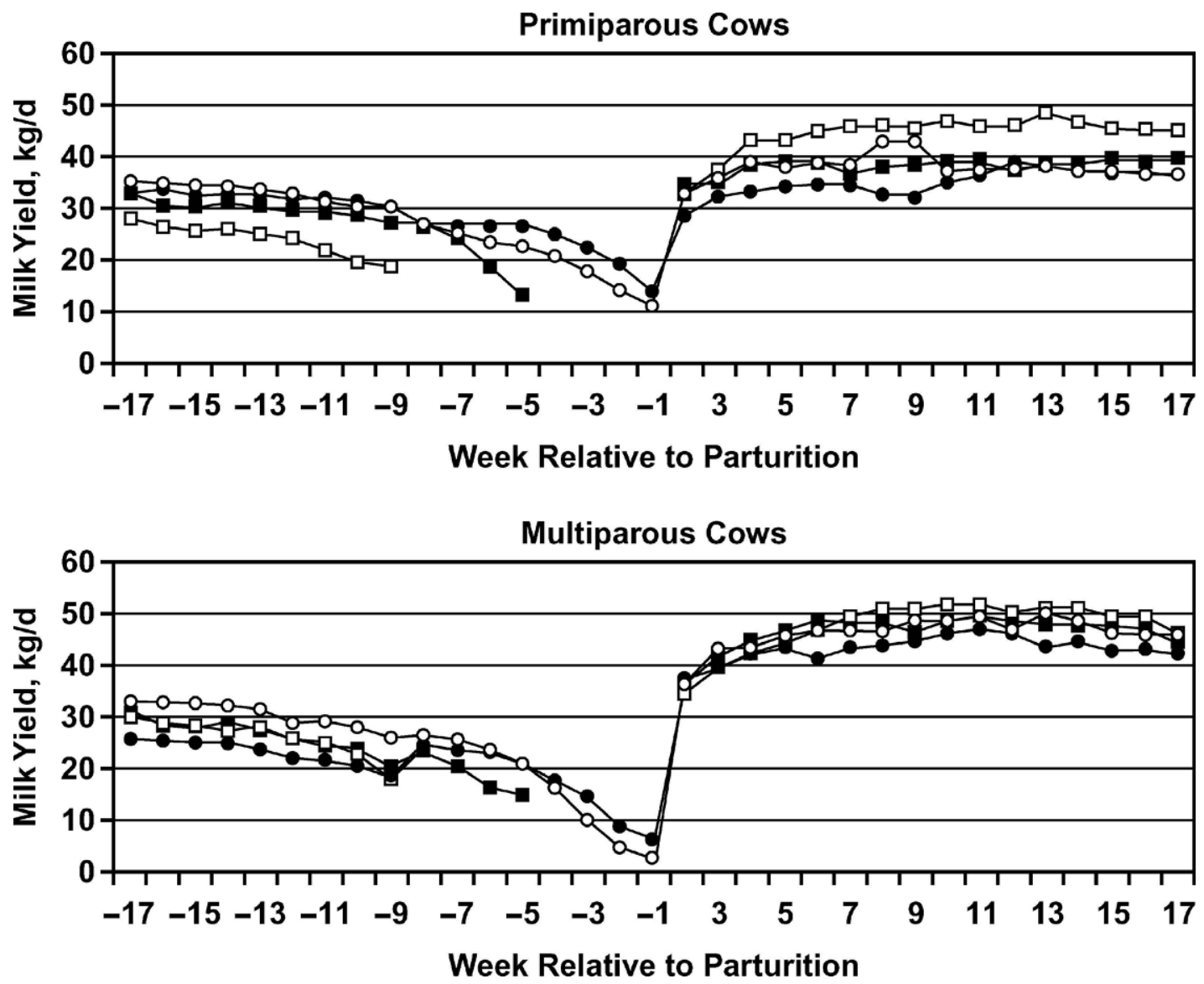

Figure 1. Milk yield during late gestation and $17 \mathrm{wk}$ of the next lactation in cows subjected to a shortened or omitted dry period and bST supplementation. $\square=60$ DD (60-d dry period, label bST supplementation), $\square=30 \mathrm{DD}$ (30-d dry period, label bST supplementation), 0 = CMLST (no dry period, label bST supplementation), and $\bigcirc=$ CMCST (no dry period, continuous bST supplementation). Week -17 to 9 are unadjusted means. All other weeks are adjusted LSM using wk -17 to -12 as the covariate. Standard error of the LSM for wk -8 to parturition is $1.7 \mathrm{~kg} / \mathrm{d}$ for primiparous cows and $2.4 \mathrm{~kg} / \mathrm{d}$ for multiparous cows. Standard error of the LSM for wk 2 to 17 is $1.8 \mathrm{~kg} / \mathrm{d}$ for primiparous cows and $2.6 \mathrm{~kg} / \mathrm{d}$ for multiparous cows.

cows, CMLST and CMCST treatments averaged 2 and $1 \mathrm{~d}$ dry, respectively (Table 1). Multiparous cows in CMLST and CMCST averaged 5 and $3 \mathrm{~d}$ dry, respectively (Table 1). These short dry periods in the CM cows resulted from cows with very low milk yields that dried spontaneously within $21 \mathrm{~d}$ of parturition. The small number of days dry in treatments CMLST and CMCST combined with only 2 cows removed because of dry periods $>21 \mathrm{~d}$ suggested that most bST-supplemented cows are able to sustain a profitable production level throughout the last $8 \mathrm{wk}$ of gestation. Another goal of the experiment, evaluating shortened or omitted dry periods in high-producing cows, was achieved with primiparous $60 \mathrm{DD}$ cows reaching peak milk yields $>45$ $\mathrm{kg} / \mathrm{d}$ and multiparous 60DD cows reaching peak milk yields $>50 \mathrm{~kg} / \mathrm{d}$ (Figure 1 ).

A total of 95 (56 primiparous and 39 multiparous) of the 120 cows originally assigned to treatment com- pleted the study and were used in all statistical analyses, except colostrum IgG content. Each treatment group had a similar number of cows removed, and no patterns existed in reasons for removing cows (Table 1). Reasons for cows exiting the study ranged from injury and health events typically observed in herds to incorrect or excessive dry period length or missed data collection for the current study. Our objective of examining the biology of a shortened or omitted dry period on subsequent milk yield resulted in 2 multiparous, CMLST cows being removed for a dry period $>21 \mathrm{~d}$; one multiparous, 30DD cow being removed for a dry period in $>60 \mathrm{~d}$ because of spontaneous drying; and 3 ( 2 primiparous, one multiparous) 30DD cows being removed as a result of being erroneously CM or dried for a projected 60-d dry period not as a result of spontaneous drying. Reassignment of those cows to treatment based on actual days dry would have violated statistical assump- 
Table 1. Summary of the number of cows in each treatment, cows removed from each treatment, days dry, and DIM at the start of the study (wk-17).

\begin{tabular}{|c|c|c|c|c|c|c|}
\hline Treatment $^{1}$ & $\mathrm{n}$ & $\mathrm{P} / \mathrm{M}^{2}$ & $\begin{array}{l}\text { Cows } \\
\text { removed }\end{array}$ & $\begin{array}{l}\text { Avg. d dry } \\
\text { P/M } \\
(\mathrm{LSM} \pm \mathrm{SEM})\end{array}$ & $\begin{array}{l}\text { Avg. DIM at } \\
\text { wk }-17 \\
(\mathrm{LSM} \pm \mathrm{SEM})\end{array}$ & Reasons for exiting the study \\
\hline 60DD & 24 & $\begin{array}{l}14 \\
10\end{array}$ & 6 & $\begin{array}{l}55 \pm 1.6 \\
63 \pm 1.9\end{array}$ & $287 \pm 12$ & $\begin{array}{l}\text { Sold-mastitis, metabolic disease, injured (3); } \\
\text { Died—sudden (1); Incorrect dry period length (2) }\end{array}$ \\
\hline 30DD & 23 & $\begin{array}{l}13 \\
10\end{array}$ & 7 & $\begin{array}{l}30 \pm 2.0 \\
32 \pm 2.0\end{array}$ & $261 \pm 12$ & $\begin{array}{l}\text { Sold-gastrointestinal compaction, Johne's disease, } \\
\text { Escherichia coli (3); Incorrect dry period length (4) }\end{array}$ \\
\hline CMLST & 22 & $\begin{array}{r}13 \\
9\end{array}$ & 8 & $\begin{array}{l}2 \pm 1.0 \\
5 \pm 2.7\end{array}$ & $272 \pm 11$ & $\begin{array}{l}\text { Died-pneumonia, sudden (3); aborted }<220 \text { d carried } \\
\text { calf (1); Sold-cancer (1); Incorrect dry period length (2); } \\
\text { No data (1) }\end{array}$ \\
\hline CMCST & 26 & $\begin{array}{l}16 \\
10\end{array}$ & 4 & $\begin{array}{l}1 \pm 0.8 \\
3 \pm 1.4\end{array}$ & $287 \pm 18$ & $\begin{array}{l}\text { Died }^{3} \text {-mycoplasma (2); Fell and injured (1); } \\
\text { No data (1) }\end{array}$ \\
\hline
\end{tabular}

${ }^{1} 60 \mathrm{DD}=60$-d dry period, label bST supplementation; 30DD = 30-d dry period, label bST; CMLST = no dry period, label bST supplementation; and CMCST $=$ no dry period, continuous bST supplementation.

${ }^{2} \mathrm{P}=$ Primiparous, $\mathrm{M}=$ multiparous.

${ }^{3}$ Contracted mycoplasma during housing with the hospital pen for colostrum sampling purposes.

tions of randomization. It should be noted that if cows with unplanned dry periods $>21 \mathrm{~d}$ for CMLST and 50 $\mathrm{d}$ for 30DD had been kept in the data, prepartum milk yield and overall economic results might have been slightly lower for these groups.

\section{Milk Yield}

Milk yield responses to treatment differed by parity and are presented separately.

\section{Primiparous}

The temporal pattern of milk production during the last $17 \mathrm{wk}$ of gestation and first $17 \mathrm{wk}$ of the subsequent lactation are presented in Figure 1. Production differences among treatment groups at the start of the study were accounted for in the statistical analyses by using data collected during wk 17 to 12 prepartum as a covariate. Weeks 11 to 9 prepartum were not used in the covariate because bST supplementation in the 60DD group was ceasing. Both CMLST and CMCST cows were on bST and were lactating during the last $17 \mathrm{wk}$ of gestation. These treatments did not differ until after parturition, in that CMCST cows received continuous bST supplementation whereas CMLST cows were not supplemented until wk 9 to 10 postpartum.

A rapid decline in prepartum milk yield was observed during the last 2 to $3 \mathrm{wk}$ of lactation in 60DD and 30DD groups as bST treatment ended. Average daily milk yield during late gestation (last $8 \mathrm{wk}$ of gestation) was affected $(P<0.01)$ by treatment, treatment $\times$ WRC, and treatment $\times$ herd. Additional days of lactation improved average daily milk yield during the prepartum period in CMLST and CMCST groups compared with 60DD and 30DD groups $(P<0.05$; Table 2$)$. Because least square means estimated for $60 \mathrm{DD}$ during the last 8 wk of gestation were not exactly equal to 0 , the data presented in Table 2 are least square means that have been adjusted to 0 for the 60DD group during the last 8 wk of gestation. Primiparous cows in CMLST and CMCST groups averaged 21.0 and $17.9 \mathrm{~kg} / \mathrm{d}$, respectively, during the last $8 \mathrm{wk}$ of gestation (Table 2). Furthermore, both treatments were still producing $>10 \mathrm{~kg} /$ $\mathrm{d}$ the last week of gestation (Figure 1). Primiparous cows in the 30DD group averaged $8.1 \mathrm{~kg} / \mathrm{d}$ during the last $8 \mathrm{wk}$ of gestation, but were only lactating $4 \mathrm{wk}$ more. During the last $4 \mathrm{wk}$ of gestation, zero milk production resulted in a reduced average daily milk yield for the 8-wk period analyzed. However, 4 wk more of lactation did result in higher $(P<0.05)$ prepartum milk yield in 30DD cows than in 60DD cows. Investigation of the treatment $\times$ herd interaction revealed lower $(P$ $<0.05$ ) milk yield in 30DD cows from herd 3 than from herd 1 (6.0 vs. $15.1 \mathrm{~kg} / \mathrm{d})$. Similar to daily milk yields during the last $8 \mathrm{wk}$ of gestation, total milk produced during this prepartum period was greatest $(P<0.01)$ in the CM groups and higher $(P<0.05)$ in the 30DD group than in the 60DD group (Figure2). Total late gestation milk yield was not affected by any variable other than treatment.

Shortening (30DD) or omitting (CMLST and CMCST) the dry period between the first and second lactations resulted in a reduction $(P<0.001)$ in daily milk yield during the first 2 to $17 \mathrm{wk}$ of the subsequent lactation compared with 60DD cows (Table 2). All treatments demonstrated similar temporal patterns in milk yield (Figure 1); however, the 30DD, CMLST, and CMCST primiparous cows reached lower $(P<0.05)$ plateaus than did 60DD cows. No difference in milk production 
Table 2. Least square means and standard errors ${ }^{1}$ for daily milk $(\mathrm{kg} / \mathrm{d})$ produced during the last 8 wk of gestation and wk 2 through 17 of the subsequent lactation.

\begin{tabular}{lccccc}
\hline & \multicolumn{4}{c}{ Treatment $^{2}$} \\
\cline { 2 - 6 } Primiparous & 60DD & 30DD & CMLST & CMCST & SE \\
\hline Daily milk for last 8 wk of gestation (kg/d) & $0.0^{\mathrm{x}}$ & $8.1^{\mathrm{y}}$ & $21.0^{\mathrm{z}}$ & $17.9^{\mathrm{z}}$ & 1.2 \\
$\quad$ Daily milk for wk 2 to 17 of the subsequent lactation (kg/d) & $44.1^{\mathrm{x}}$ & $38.3^{\mathrm{y}}$ & $35.1^{\mathrm{y}}$ & $37.5^{\mathrm{y}}$ & 1.3 \\
Multiparous & & & & & \\
$\quad$ Daily milk for last 8 wk of gestation (kg/d) & $8.2^{\mathrm{y}}$ & $15.0^{\mathrm{z}}$ & $13.8^{\mathrm{z}}$ & 1.8 \\
Daily milk for wk 2 to17 of the subsequent lactation (kg/d) & 47.7 & 46.6 & 43.4 & 46.5 & 2.1 \\
\hline
\end{tabular}

${ }^{1}$ Least square means were adjusted using data collected from 17 wk to 12 wk prepartum as a covariate.

${ }^{2} 60 \mathrm{DD}=60$-d dry period, label bST supplementation; 30DD = 30-d dry period, label bST supplementation; CMLST = no dry period, label bST supplementation; and CMCST = no dry period, continuous bST supplementation.

${ }^{\mathrm{x}, \mathrm{y}, \mathrm{z}}$ Means within a row with different superscripts differ $(P<0.05)$.

was found between the $2 \mathrm{CM}$ groups and the 30DD group. Throughout the first 2 to $17 \mathrm{wk}$ of the subsequent lactation, primiparous cows in 30DD, CMLST, and CMCST groups, respectively, produced 87,80 , and $85 \%$ as much as 60DD cows (Table 2). Additional body and mammary growth in primiparous cows may require a dry period $>30 \mathrm{~d}$. Thus, reduced milk yield in primiparous 30DD and CM cows might have been the result of reduced mammary growth, reduced mammary functionality, or a combination of both. Subsequent milk yield also was affected $(P \leq 0.05)$ by breed. Holstein cows had higher milk yields than Brown Swiss cows (39.6 vs. $35.4 \mathrm{~kg} / \mathrm{d})$.

Total milk produced during the subsequent lactation (wk 2 to 17 ) was lower $(P<0.05)$ in the CMLST group compared with the 60DD group, but CMCST and 30DD groups did not differ from the 60DD group or CMLST group (Figure 2). Combined total milk produced during the last $8 \mathrm{wk}$ of gestation and first 2 to $17 \mathrm{wk}$ postpartum was not affected $(P>0.05)$ by any of the independent variables in the statistical model (Figure 2). Milk produced during the last $8 \mathrm{wk}$ of gestation and/or the absence of differences among some treatments for total postpartum milk resulted in no treatment differences in combined total milk, despite the reductions in average daily milk yield during wk 2 to 17 postpartum for the 30DD and CM groups.

\section{Multiparous}

In multiparous cows, analysis of average daily milk yield during the last 8 wk of gestation detected no differences $(P>0.05)$ between CMLST and CMCST groups (Table 2). Both CM groups had higher $(P<0.01)$ milk yields than the 60DD and 30DD groups, and milk yield for the 30DD group was higher $(P<0.05)$ than that for the 60DD group. As mentioned for primiparous cows, data presented in Table 2 are least square means that have been adjusted to 0 for the 60DD group during the last 8 wk of gestation. The temporal pattern of milk production during the last $17 \mathrm{wk}$ of gestation was similar to that observed in primiparous cows (Figure 1), but multiparous cows were less persistent and the production decline during the last 3 wk of gestation was more dramatic. Cessation of bST supplementation in 60DD and 30DD groups resulted in substantial decreases in milk yield during their last 2 to $3 \mathrm{wk}$ of lactation. During the final 3 wk of gestation, multiparous, CMLST, and CMCST cows produced $10 \mathrm{~kg} / \mathrm{d}$ or less milk (Figure 1). This decrease in milk yield is exacerbated by the fact that some CM cows had spontaneously dried and were producing $0 \mathrm{~kg} / \mathrm{d}$ during this time period. Cows that were actually lactating had higher milk yields than suggested by the least square means for each group during these weeks. Similar to primiparous cows, production differences among treatment groups at the start of the study were accounted for in the statistical analyses by using data collected during wk 17 to 12 prepartum as a covariate.

Average daily milk yield during late gestation was lower in multiparous cows than in primiparous cows (Table 2). Milk yield during the last 8 wk of gestation by CMLST and CMCST multiparous cows were 23 to $29 \%$ lower than milk yields of the respective primiparous cows. Less lactation persistency in CM multiparous cows was also suggested by longer days dry in CMLST and CMCST groups than observed in primiparous cows (Table 1 ). Average daily milk yield during late gestation was also affected $(P<0.05)$ by herd, breed, treatment $\times$ herd, and treatment $\times$ herd $\times$ WRC in multiparous cows. The treatment $\times$ herd interaction demonstrated that herd 2 had lower $(P<0.05)$ milk yield from CMLST and CMCST cows than did herds 1 and 3 (data not shown).

For multiparous cows, total milk produced during the last 8 wk of gestation was greater in both CM groups and the 30DD group compared with the 60DD group (Figure 2). As expected, total milk produced during late 
Primiparous Cows
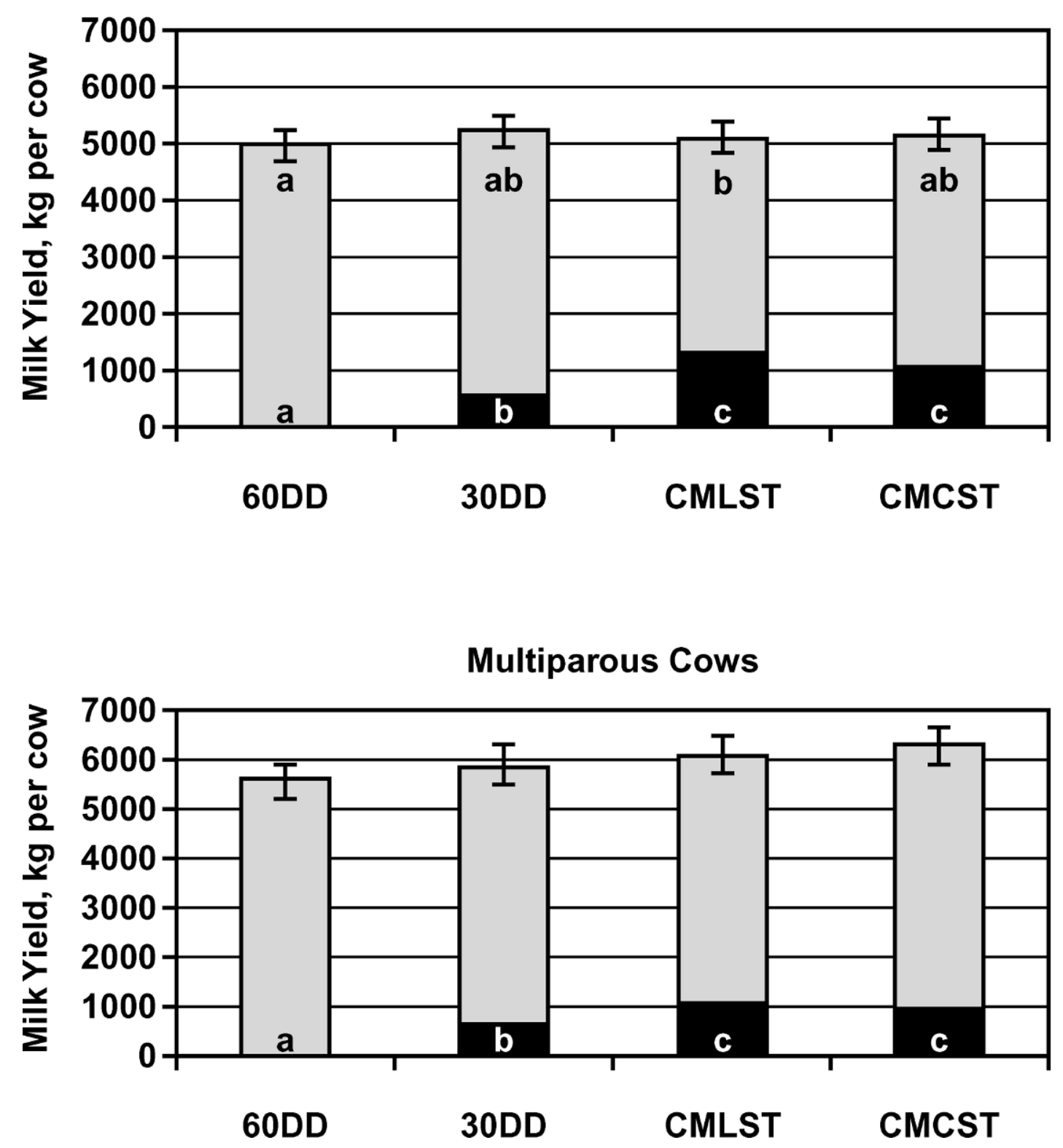

Figure 2. Total milk production during the last $8 \mathrm{wk}$ of gestation and first $17 \mathrm{wk}$ of the subsequent lactation. $60 \mathrm{DD}=60-\mathrm{d}$ dry period, label bST supplementation; 30DD = 30-d dry period, label bST supplementation; CMLST = no dry period, label bST supplementation; and CMCST = no dry period, continuous bST supplementation. Gray shaded areas are total milk produced during the first $17 \mathrm{wk}$ of the subsequent lactation; black shaded areas are total milk produced during the last $8 \mathrm{wk}$ of gestation, and the combined black and gray areas are total milk produced during the last 8 wk of gestation and first $17 \mathrm{wk}$ of the subsequent lactation. No treatment effects were detected $(P>0.05)$ for total milk produced ( 8 wk prepartum to 17 wk postpartum) for primiparous or multiparous cows. Total milk produced during late gestation (last $8 \mathrm{wk}$ of gestation) was affected $(P<0.05)$ by treatment for both parities. Total milk produced during early lactation $(2$ to 17 wk of the subsequent lactation) was altered $(P<0.05)$ by treatment in primiparous cows, but not $(P>0.1)$ in multiparous cows. Different LSM are indicated by different letters in the black and gray shaded areas. All LSM were adjusted using data collected from wk 17 to 12 prepartum as a covariate.

gestation was greater in CM treatments than in 30DD and did not differ between the $2 \mathrm{CM}$ treatments. Total late gestation milk yield was also affected $(P<0.05)$ by breed (herd) and herd $\times$ treatment. Brown Swiss cows in herd 3 produced less $(P<0.05)$ milk than Holsteins in herds 1 and 3 (data not shown). Holsteins in herd 2 produced less $(P<0.05)$ milk during late gestation than Holsteins in herds 1 and 3 (data not shown). The herd 
$\times$ treatment interaction revealed higher $(P<0.01)$ total prepartum milk yield in herd 3 CMLST cows than in herd 2 CMLST cows (1740.9 vs. $514.5 \mathrm{~kg}$ per cow). Total late gestation milk yield and average daily milk yield during the prepartum period would be slightly lower if CMLST and 30DD cows that spontaneously dried were included in the analysis.

Unlike primiparous cows, shortening (30DD) or omitting (CMLST and CMCST) the dry period did not alter $(P>0.5)$ milk yields in the subsequent lactation (Table 2 ). All treatments demonstrated similar lactation curves during the first 2 to 17 wk postpartum; daily milk yield increased rapidly during the first 2 wk postpartum, reached peak milk yield between wk 8 to 10 , and lactation curves reached a plateau at similar production levels (Figure 1). Total milk produced from wk 2 to 17 postpartum and combined total milk yield from $8 \mathrm{wk}$ prepartum to $17 \mathrm{wk}$ postpartum were not altered $(P>0.05)$ by any of the independent variables in the statistical model (Figure 2). The absence of a treatment effect on total milk yield despite 4 to 8 wk of additional milking in 30DD, CMLST, and CMCST cows and no production losses in the subsequent lactation may be the result of less persistent milk yield during late gestation and more variability in daily milk production in multiparous cows.

There have not been other studies evaluating continuous milking and bST supplementation, and few studies have evaluated a shortened or omitted dry period, discussing parity differences. Similar to the current study, Rémond et al. (1992) demonstrated a 17\% reduction in milk yield in CM primiparous cows. Rémond et al. (1997) reviewed a large commercial trial (Brittany Survey) in which production losses were greater in CM primiparous cows than in CM multiparous cows (1525 and $1342 \mathrm{~kg}$, respectively). Those researchers also concluded that continued body and mammary growth in primiparous cows exacerbated production losses after a shortened or omitted dry period. Furthermore, some studies analyzing dairy records also detected a greater sensitivity of a reduced or omitted dry period between the first and second lactations than in older cows (Wilton et al., 1967; Dias and Allaire, 1982). Dias and Allaire (1982) determined that the dry period requirement decreased from 65 to $23 \mathrm{~d}$ as age during the preceding lactation increased from 24 to 83 mo. Sørensen and Enevoldsen (1991) were not able to demonstrate a parity effect in an evaluation of a dry period shortened to $4 \mathrm{wk}$ and reported a $10 \%$ reduction in milk yield during $168 \mathrm{~d}$ of the next lactation across all cows. Data from observational studies (Wilton et al., 1967; Dias and Allaire, 1982) might have biased interpretations because animals were not actually being managed for shortened or omitted dry periods. Factors such as mismanage- ment, health status, multiple births, gestation length, and inaccurate breeding records might have biased the data (Rémond et al., 1997). Others have demonstrated reduced milk yields in CM cows, but did not discuss parity differences (Swanson, 1965; Smith et al., 1967; Rastani et al., 2003).

Similar subsequent milk yields in CM multiparous cows (CMLST and CMCST) and 60DD cows (Table 2) have not been previously reported. This is the first study to investigate CM in high-producing, bST-supplemented cows. We hypothesize that the bST-mediated effects on MEC during late gestation might have improved MEC functionality and/or replacement of senescent MEC in CM cows. Data of Capuco et al. (2001, 2003) suggest that bST administration increases turnover and functionality of MEC. This hypothesis is also supported by data from Rastani et al. (2003) in which high-producing cows that were CM but not supplemented with bST had production losses of $14.8 \%$ compared with 56-d dry cows. This $14.8 \%$ decrease and historical decreases of 17 to $38 \%$ in lower-producing cows (Swanson, 1965; Smith et al., 1967; Rémond et al., 1992), when no bST supplementation occurred, are in contrast to no significant production losses observed when CM cows received bST during late gestation (CMLST) or during late gestation and early lactation (CMCST). Data from studies using 30-d dry periods demonstrate equal milk yields in cows given 30- and 60-d dry periods with and without bST (Bachman, 2002; Gulay et al., 2003, 2004; Rastani et al., 2003). This consensus observation suggests that bST administered during the additional $4 \mathrm{wk}$ of lactation is not required for normal production levels in the subsequent lactation. In contrast, CM cows apparently will require supplementation with bST throughout late gestation not only to sustain profitable milk production but to achieve subsequent production levels that are equal to those of 30DD and 60DD cows. Notably, Gulay et al. (2004) have observed that, with dry period lengths of 30 and $60 \mathrm{~d}$, low doses of bST during the transition period and early lactation improved milk yield. The numerical increase in milk production of the CMCST cows compared with CMLST (Table 2) may suggest that bST given during early lactation might contribute to the improvement of milk production in CM cows, primiparous or multiparous.

In comparison with $60 \mathrm{DD}$, no difference in milk yield was demonstrated in the current study for multiparous 30DD cows. Other experiments have evaluated a shortened dry period (<40 d) (Coppock et al., 1974; Lotan and Alder, 1976; Sørensen and Enevoldsen, 1991; Bachman, 2002; Rastani et al., 2003) without bST, and Gulay et al. $(2003,2004)$ have evaluated a shortened dry period with administration of a low dose of bST (143 mg/14 d 
Table 3. Summary of milk composition and colostrum IgG content in the subsequent lactation of cows subjected to a shortened or omitted dry period. ${ }^{1}$

\begin{tabular}{|c|c|c|c|c|c|}
\hline \multirow[b]{2}{*}{ Milk composition } & \multicolumn{5}{|c|}{ Treatment $^{2}$} \\
\hline & $60 \mathrm{DD}$ & $30 \mathrm{DD}$ & CMLST & CMCST & $\mathrm{SE}$ \\
\hline \multicolumn{6}{|l|}{ Primiparous } \\
\hline Milk fat, $\%$ & 3.67 & 3.71 & 3.79 & 3.62 & 0.22 \\
\hline Milk true protein, \% & $2.85^{\mathrm{x}}$ & $3.16^{\mathrm{y}}$ & $3.04^{\mathrm{y}}$ & $3.06^{\mathrm{y}}$ & 0.06 \\
\hline Somatic cell linear score & 1.24 & 1.89 & 2.40 & 2.55 & 0.39 \\
\hline \multicolumn{6}{|l|}{ Multiparous } \\
\hline Milk fat, \% & 3.56 & 3.28 & 3.54 & 3.63 & 0.17 \\
\hline Milk true protein, $\%$ & 2.78 & 2.90 & 2.94 & 2.91 & 0.06 \\
\hline Somatic cell linear score & 1.18 & 2.01 & 2.16 & 3.44 & 0.68 \\
\hline
\end{tabular}

${ }^{1}$ Milk samples were collected monthly for the first 4 mo postpartum (except colostrum), and composition was evaluated. Means were adjusted using data collected from wk 17 to 12 prepartum as a covariate.

${ }^{2} 60 \mathrm{DD}=60$-d dry period, label bST supplementation; 30DD = 30-d dry period, label bST supplementation; $\mathrm{CMLST}=$ no dry period, label bST supplementation; and CMCST = no dry period, continuous bST supplementation.

${ }^{\mathrm{x}, \mathrm{y}}$ Means within a row with different superscripts differ $(P<0.05)$.

compared with the FDA-approved dose of $500 \mathrm{mg} / 14 \mathrm{~d}$ ) during late gestation and early lactation. Similar to the current study, a majority of these studies had no difference in 305-d milk yield (Lotan and Alder, 1976; Bachman, 2002) or daily milk yield (Gulay et al., 2003, 2004; Rastani et al., 2003) for cows dry $30 \mathrm{~d}$ compared with cows dry 60 d. Gulay et al. (2003, 2004) did not detect an interaction of dry period length and bST supplementation. Coppock et al. (1974) observed production losses of $\leq 10 \%$ in cows dry 20,30 , or $40 \mathrm{~d}$, and Sørensen and Enevoldsen (1991) observed production losses of $10 \%$ in cows dry 4 wk. The results of these studies were not separated into first and later parities, but parities were balanced in many of these studies (Lotan and Alder, 1976; Bachman, 2002; Gulay et al., 2003). Consistent reports (Lotan and Alder, 1976; Bachman, 2002, Gulay et al., 2003, Rastani et al., 2003) of negligible production losses in cows given a 30-d dry period suggest that a 30 -d dry period may be a feasible dairy management practice for multiparous cows.

\section{Milk Composition}

Milk fat content was unaffected $(P>0.05)$ by any of the treatments regardless of parity (Table 3 ). In multiparous cows, milk fat percentage was altered by breed, with Brown Swiss cows producing milk with a higher $(P<0.05)$ milk fat content than Holsteins $(4.25 \%$ vs. $3.36 \%$, respectively). Other researchers have also demonstrated no effect of shortened or omitted dry periods on milk fat concentrations (Rémond et al., 1992, 1997; Gulay et al., 2003). For both parities, milk fat percentage in all treatments was highest in the first month postpartum and declined thereafter (data not shown).
As reported for milk fat percentage, milk protein was also highest in the first month postpartum and slowly declined through 4 mo postpartum regardless of parity (data not shown). In primiparous cows, milk protein content was higher $(P<0.05)$ in 30DD, CMLST, and CMCST compared with 60DD (Table 3). However, in multiparous cows, milk protein was not altered by treatment. A shortened or omitted dry period has been shown to increase (Rémond et al., 1992, 1997) or not alter (Smith et al., 1967; Gulay et al., 2003) milk protein percentage in CM or 30-d dry cows. A greater percentage of protein in some studies may be the result of reduced milk yield improving energy balance, thus sparing amino acids and energy for protein synthesis or a reduced dilution effect caused by lower milk yields (Rémond et al., 1997). The fact that milk protein was only increased in primiparous cows suggests that the reduction in milk yield was an important factor in this treatment response. The treatment $\times$ breed interaction in multiparous cows revealed that CMCST Brown Swiss cows had higher milk protein content than CMCST Holstein cows in herds 1 and $2(3.46 \%$ vs. 2.76 and 2.84\%; herd 3 Brown Swiss vs. herd 1 and 2 Holsteins).

The impact of shortened and omitted dry periods on udder health and milk quality is an important factor for dairy producers to consider, especially because mastitis accounts for $62 \%$ of cows culled for slaughter (NAHMS, 1996). The dry period brings high risks for new infections to be introduced into the mammary gland, which would increase the risk of clinical mastitis in early lactation (Green et al., 2002). The risk of new infections during the dry period is greatest during udder engorgement in the early dry period and just before calving 
(Smith et al., 1985), as well as during administration of intramammary antibiotics if technique is poor. Continuous milking removes these risks for increased mastitis during the dry period, but imposes the risk of increased SCC because cows are not treated with longacting, intramammary antibiotics. The latter concern may be of particular importance in cows with high SCC, perhaps making a dry period necessary for high SCC cows (especially those with subclinical environmental organisms). Rémond et al. (1997) discussed the impact of no dry period on SCC using data from several studies (controlled and commercial field trials). In subsequent lactations, Rémond et al. (1997) observed a tendency for SCC to increase in cows having received a shortened or omitted dry period, but the increase was not accompanied by an increase in clinical mastitis cases. Results from the current study demonstrate no effect $(P>0.1)$ of treatment on SCS (Table 3). There was a tendency for increased SCS in CMCST multiparous cows, but large between-animal variability in SCS data makes interpretation of these data difficult for this number of cows. It is important to point out that all treatments maintained low reported SCS values, which translate to an SCC ranging from 28,400 to 136,000 cell s $/ \mathrm{mL}$. In multiparous cows, SCS was affected $(P<0.05)$ by herd. Herd 3 had a higher SCS than herds 1 and 2 (3.50 vs. 1.38 and 1.71).

Research has shown a reduction in colostral immunoglobulin and protein content in CM cows (Rémond et al., 1997). Prepartum milking of udder halves to induce premature lactogenesis reduced $\mathrm{IgG}_{1}$ concentrations in milked glands compared with secretions from unmilked glands from $10 \mathrm{~d}$ prepartum to $1 \mathrm{~d}$ postpartum (Guy et al., 1994b). Additionally, Guy et al. (1994b) reported that cows that responded to prepartum milking and produced $>4 \mathrm{~L} / \mathrm{d}$ in milked glands before parturition had lower colostrum IgG concentrations than nonresponders $(<4 \mathrm{~L} / \mathrm{d})$. These data suggest both a dry period and milk yield component in determining colostral IgG levels. In humans, an overlap of breastfeeding and late pregnancy also results in reduced Ig concentrations in colostrum (Marquis et al., 2003). Accumulation of secretions in the mammary gland before parturition results in enhanced protein and Ig concentrations in colostrum (Wheelock et al., 1965; Rémond et al., 1997). Continuously milked cows may have reduced colostrum quality because of the lack of a secretion accumulation period. Others have shown that CM of glands maintains milk production but simultaneously reduces the transfer of $\mathrm{IgG}_{1}$ into secretions from milked glands (Brandon and Lascelles, 1975).

In the current study, analysis of first-milking or presumptive first-milking IgG values for primiparous cows $(\mathrm{n}=36)$ from herds 2 and 3 revealed significant treat- ment and herd effects $(P<0.05)$. Colostrum IgG content was reduced in CMLST and CMCST primiparous cows compared with 30DD primiparous cows (5.8 and $4.1 \pm$ 1.4 vs. $9.0 \pm 1.2 \mathrm{mg} / \mathrm{mL}$, respectively). Additionally, IgG values were lower in colostrum from CMCST primiparous cows compared with $60 \mathrm{DD}$ primiparous cows (4.1 \pm 1.5 vs. $8.4 \pm 1.3 \mathrm{mg} / \mathrm{mL}$, respectively). There were no differences between 60DD and 30DD groups, between CMLST and CMCST groups, or between 60DD and CMLST groups, although CMLST IgG values were $45 \%$ lower than 60DD IgG values. Herd 2 had higher colostral IgG concentrations than herd $3(8.9 \pm 1.6$ vs. 4.8 $\pm 0.8 \mathrm{mg} / \mathrm{mL}$, respectively). This herd effect is likely because thrice daily milking in herd 2 resulted in colostrum sampling occurring closer to parturition than in herd 3, which was milked twice daily, and because calves were allowed to be with dams for $12 \mathrm{~h}$ in herd 3. Decreasing IgG concentrations as hours after parturition increase has also been described in colostrum from ewes (Mazzone et al., 1999).

In multiparous cows $(\mathrm{n}=35)$, treatment did not alter $(P>0.7)$ first-milking colostrum IgG concentration. Treatment means for first-milking colostrum from multiparous cows were $9.3,9.6,6.7$, and $9.2 \pm 1.8 \mathrm{mg} / \mathrm{mL}$ (60DD, 30DD, CMLST, and CMCST, respectively). First-milking IgG concentration in multiparous cows was also affected $(P=0.05)$ by breed. Colostrum from Holstein cows had higher IgG content than colostrum from Brown Swiss cows $(11.2 \pm 1.4$ vs. $6.3 \pm 1.6 \mathrm{mg} / \mathrm{mL}$, respectively). Differences caused by breed are unexplained and are likely the result of small animal numbers and only herd 3 using Brown Swiss cows.

To evaluate the sensitivity of colostrum IgG content to hours after parturition, an analysis of IgG content during each of the first 4 milkings was conducted for herd 3 data. For both primiparous and multiparous cows, IgG content was affected $(P<0.001)$ by milking number relative to parturition. Immunoglobulin G content was highest at the first milking postpartum and declined thereafter, regardless of treatment. By the fourth milking after parturition $(\sim 30$ to $48 \mathrm{~h}$ postpartum), IgG levels were only $1.6 \pm 0.5 \mathrm{mg} / \mathrm{mL}$ and were very similar across both parities and all treatments. As previously mentioned, data of Mazzone et al. (1999) demonstrate decreasing IgG concentrations as hours after parturition increased. For both parities, treatment effects from this herd 3 analysis were similar to the results of the first-milking analysis conducted with data from both herds 2 and 3 . For primiparous cows, the treatment effects persisted through the first 2 milkings after parturition (milking number $\times$ treatment; $P<$ 0.001). During the first milking after parturition, IgG content was reduced in CMLST and CMCST compared with $60 \mathrm{DD}$ and $30 \mathrm{DD}$ (3.0 and $2.0 \pm 0.8$ vs. 6.1 and 8.4 
$\pm 0.9 \mathrm{mg} / \mathrm{mL}$, respectively). At the second milking after parturition, 30DD cows had higher IgG content than CMLST or CMCST ( $4.3 \pm 0.9$ vs. 1.8 and $1.1 \pm 0.9 \mathrm{mg} /$ $\mathrm{mL}$, respectively), and IgG content from 60DD cows was intermediate and not different from any of the other treatments $(3.0 \pm 0.9 \mathrm{mg} / \mathrm{mL})$. No treatment differences were detected for the third (mean $=1.8 \pm 0.8 \mathrm{mg} / \mathrm{mL}$ ) and fourth (mean $=1.3 \pm 0.8 \mathrm{mg} / \mathrm{mL}$ ) milkings after parturition. Consistent with the first-milking colostrum anlaysis, no effect of treatment on colostrum IgG content was detected for multiparous cows.

The absence of a treatment effect on colostrum IgG content in multiparous cows but reduced colostrum IgG content in CM primiparous cows might have been the result of more and longer unplanned, short dry periods and lower prepartum milk yields in CM multiparous cows. Others have demonstrated a dilution of IgG content in colostrum from milked vs. unmilked glands (Guy et al., 1994b) and in higher yielding cows or glands (Guy et al., 1994a, b). Studies evaluating the number of days dry that are required for colostrum IgG concentrations similar to cows managed for a traditional dry period are limited. Rémond et al. (1997) reported that cows given a dry period of 1 to $10 \mathrm{~d}$ produced firstmilking colostrum with Ig concentrations that were similar to colostrum from cows given a 60 -d dry period ( $63 \pm 19$ vs. $72 \pm 14 \mathrm{~g} / \mathrm{L} ; 1$ to 10 -d dry vs. 60 -d dry). To further examine the effect of actual days dry on firstmilking colostrum IgG content, a retrospective analysis was done using first-milking data from herd 3 and presumptive first-milking data from herd 2 for cows across parities. Based on number of actual days dry, mean \pm $\mathrm{SE}$ values for IgG in first milkings were $5.2 \pm 0.9,14.1$ $\pm 3.2,11.1 \pm 2.8,10.7 \pm 1.5,7.1 \pm 1.2$, and $9.2 \pm 0.9 \mathrm{mg} /$ $\mathrm{mL}$ for $0 \mathrm{~d}, 1$ to $10 \mathrm{~d}, 11$ to $20 \mathrm{~d}, 21$ to $30 \mathrm{~d}, 31$ to 45 $\mathrm{d}$, and $>45 \mathrm{~d}$ dry, respectively. Cows with actual $0 \mathrm{~d}$ dry had lower $(P<0.05)$ average IgG concentrations during the first milking after parturition than cows with either very short ( 1 to $10 \mathrm{~d}$ ) or longer dry periods. Cows with even a very short dry period ( 1 to $10 \mathrm{~d}$ ) had IgG levels similar to cows dry $>45 \mathrm{~d}$ (14.1 vs. $9.2 \pm 2.1$ $\mathrm{mg} / \mathrm{mL}$, respectively). These data suggest that complete omission of the dry period would likely result in reduced colostrum quality. Varying cow numbers at each of the categories of dry period length might have biased the outcome because the experiment was not specifically designed for this analysis.

In the current study, estimates of IgG content in firstmilking samples were considerably lower than reported in the literature (Brandon et al., 1971; Husband et al., 1972; Brandon and Lascelles, 1975; Rémond et al., 1997; Godden et al., 2003). However, all of these experiments (except Rémond et al., 1997, methods unknown) used a radial immunodiffusion assay to quantify IgG content. Others have assayed for IgG using a RIA and reported values more similar to those in the current study (Guy et al., 1994a, b; Mazzone et al., 1999). For example, Guy et al. (1994a) reported IgG content of $14.4 \mathrm{mg} / \mathrm{mL}$ at parturition in dairy cows. The RIA used in the current study has been validated and published (Mazzone et al., 1999; Richards et al., 1999; Duff et al., 2000). In colostrum from ewes at $0 \mathrm{~h}$ after parturition, Mazzone et al. (1999) reported $42.6 \mathrm{mg} / \mathrm{mL}$ of IgG, demonstrating that the assay will detect higher levels of IgG. Other factors that may impact colostrum IgG levels between experiments are sampling time relative to parturition and a dilution effect in cows producing larger volumes of colostrum. Data of Mazzone et al. (1999) show a substantial decrease in colostrum IgG content between 0 and $12 \mathrm{~h}$ postpartum (42.6 vs. 14.3 $\mathrm{mg} / \mathrm{mL}$, repectively). By $18 \mathrm{~h}$ postpartum, IgG content in ewe colostrum had decreased to $5.6 \mathrm{mg} / \mathrm{mL}$. In the current study, first-milking samples were taken within $12 \mathrm{~h}$ after parturition, and IgG values were similar to values from 12- and 18-h samples from Mazzone et al. (1999). Within herds 2 and 3, if parturition takes place at or near milking, the cow is not milked until the following milking. Therefore, none of the colostrum samples taken in the current study were taken immediately after parturition. Regardless of the assay technique, colostrum samples from other studies (Brandon et al., 1971; Husband et al., 1972; Guy et al., 1994b; Mazzone et al., 1999) that were taken within 2 to $3 \mathrm{~h}$ of partition had higher IgG values than reported for the current study. The dilution of IgG content in higheryielding cows has been suggested by Guy et al. (1994a) in a study comparing colostrum from dairy and beef cows. At parturition, IgG content of beef colostrum was $83.6 \mathrm{mg} / \mathrm{mL}$ and $14.4 \mathrm{mg} / \mathrm{mL}$ in Holstein colostrum. The cows in the current study are higher-yielding cows than were used in older literature (Brandon et al., 1971; Husband et al., 1972; Brandon and Lascelles, 1975) and the cows used in the work by Rémond et al. (1997). Thus, dilution of colostral IgG concentrations could be one of the causative factors for lower IgG values in the current study. If IgG content is lower in high-producing cows, the colostrum feeding practices, 4 qt within the $3 \mathrm{~h}$ after parturition, used by the herds in the current study would be critical in elevating calf serum IgG to adequate levels. Further research is needed to verify the effect of continuous milking on colostrum IgG levels and the actual number of days dry required for normal colostrum quality. Additionally, research comparing RIA and radial immunodiffusion IgG assays is needed to determine whether results from these assays are comparable.

Mammary secretions in the last 2 wk of gestation may be altered by colostrum production or a change in 
Table 4. Summary of reproductive variables in cows subjected to a shortened or omitted dry period and bST supplementation.

\begin{tabular}{|c|c|c|c|c|c|}
\hline Treatment $^{1}$ & $\mathrm{n}$ & $\begin{array}{l}\text { Number } \\
\text { and } \\
\text { percentage } \\
\text { pregnant }^{2}\end{array}$ & $\mathrm{~S} / \mathrm{C}^{3}$ & $\begin{array}{l}\text { DIM at } \\
\text { first } \\
\text { estrus }\end{array}$ & $\begin{array}{l}\text { DIM at } \\
\text { conception }\end{array}$ \\
\hline 60DD & 24 & 16 of $24(67 \%)$ & 3.4 & $47 \pm 5$ & $74 \pm 3$ \\
\hline 30DD & 23 & 19 of $23(83 \%)$ & 2.2 & $39 \pm 5$ & $71 \pm 4$ \\
\hline CMLST & 22 & 15 of $22(68 \%)$ & 3.1 & $42 \pm 5$ & $83 \pm 4$ \\
\hline CMCST & 26 & 21 of $26(81 \%)$ & 1.9 & $53 \pm 5$ & $76 \pm 4$ \\
\hline
\end{tabular}

${ }^{1} 60 \mathrm{DD}=60$-d dry period, label bST supplementation; 30DD = 30-d dry period, label bST supplementation; CMLST $=$ no dry period, label bST supplementation; and CMCST = no dry period, continuous bST supplementation.

${ }^{2}$ Data were collected through 17 wk postpartum.

${ }^{3} \mathrm{~S} / \mathrm{C}=$ Services per conception.

primary secretion that has a composition similar to plasma (Wheelock et al., 1965). Colostrum production and secretion begins before parturition in some CM cows. In the current study, prepartum colostrum production resulted in some cows being misidentified as having mastitis. Changes in mammary secretion from normal milk to a transudate of plasma may be the result of leaky tight junctions allowing more extracellular fluid into alveolar lumens (Linzell and Peaker, 1974). Furthermore, secretions from dry cows and goats in midgestation were almost devoid of lactose and had sodium, potassium, and chloride concentrations similar to extracellular fluid (Maule-Walker, 1984). Very low milk yields in some CM cows immediately before parturition may result in a secretion that is more similar to dry secretions than milk. These changes in the physical properties and composition of prepartum mammary secretions, which may alter the appearance and consistency of milk and result in cows being identified as having mastitis, raise questions of salable milk and warrant further research.

\section{Reproduction, Economics, and Management}

Other aspects of shortened and omitted dry periods combined with bST supplementation that are important to dairy producers are reproductive performance, economics, and management of late gestation, lactating cows. Reproductive data on percentage of cows pregnant, services per conception, DIM at first estrus, and DIM at conception for each of the treatments are summarized in Table 4 . Because of the lack of statistical power for an analysis of reproductive parameters, no conclusions can be made from these data, but it appears that all treatments had similar reproductive success.

The economics of a shortened dry period, no dry period with label bST supplementation, and no dry period with continuous bST supplementation were analyzed by evaluating the CNM of each of these treatments relative to controls (60DD). Means from each treatment group presented in Figure 1 were used to estimate CNM values. It should be noted that economic differences were not subjected to tests of statistical differences, and some of the means used in calculations were not different. Therefore, interpretation of these values should be done with caution. Accumulation of the CNM began at $8 \mathrm{wk}$ before parturition, when 60DD cows were dry, but the other treatments were beginning periods of additional milk income. Although primiparous cows in 30DD and CM treatments generated a relative financial benefit before parturition, the superior postpartum milk yield in the 60DD group quickly eroded their positive CNM (Figure 3). Consequently, the 30DD group was at a net financial loss, whereas the CMLST and CMCST groups were at break-even economic performance relative to 60DD by the end of wk 17 of the subsequent lactation. All indications are that each of these 3 primiparous treatment groups would have lost substantial amounts of money over the duration of the lactation compared with the 60DD treatment group.

In the multiparous cows, groups 30DD, CMLST, and CMCST all generated beneficial CNM before parturition, and, in fact, the 30DD and CMLST groups continued to gain benefit until wk 6 and 4 of lactation, respectively (Figure 3 ). The CMCST group similarly did not begin to lose benefit to the 60DD group until wk 5 of lactation, when mathematically increased production in the 60DD group resulted in higher milk revenue. Because production levels for all treatments were not different, the CNM benefit was not rapidly eroded by the 60DD group in the postpartum period in multiparous cows (Figure 3 ). As a result, each group maintained a $\$ 40$ to $\$ 60$ benefit through the end of the treatment period. Similar production levels at wk 17 postpartum (Figure 1) indicate that a positive CNM over $60 \mathrm{DD}$ cows may be maintained throughout the lactation. 


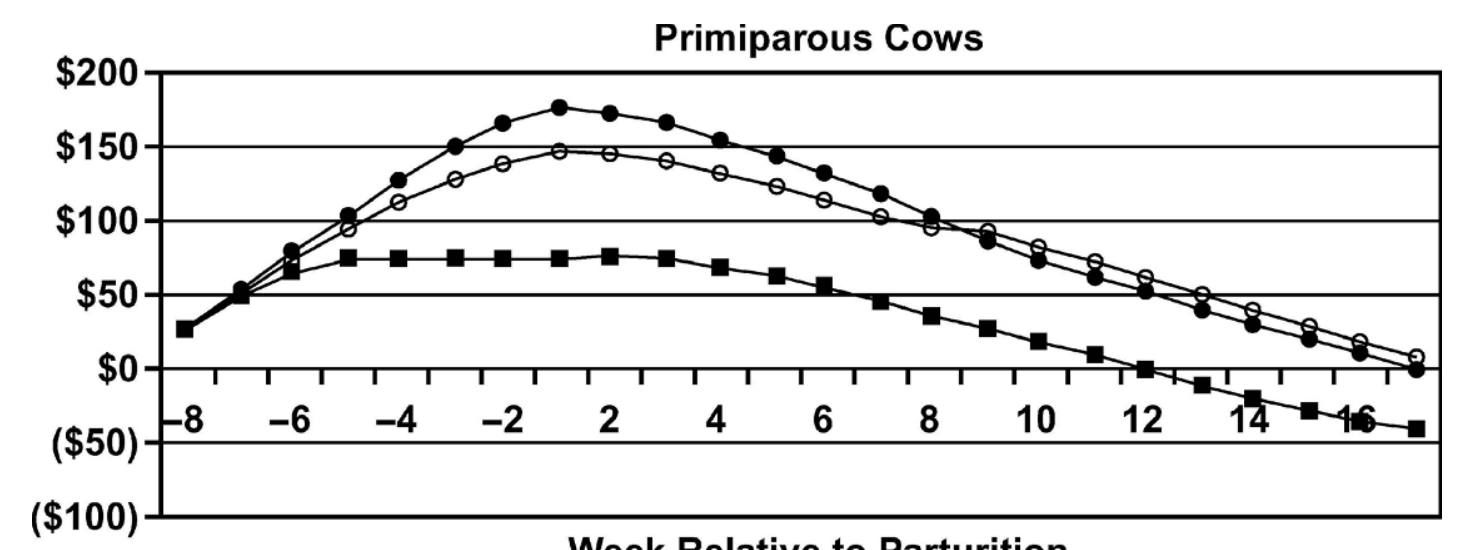

Week Relative to Parturition

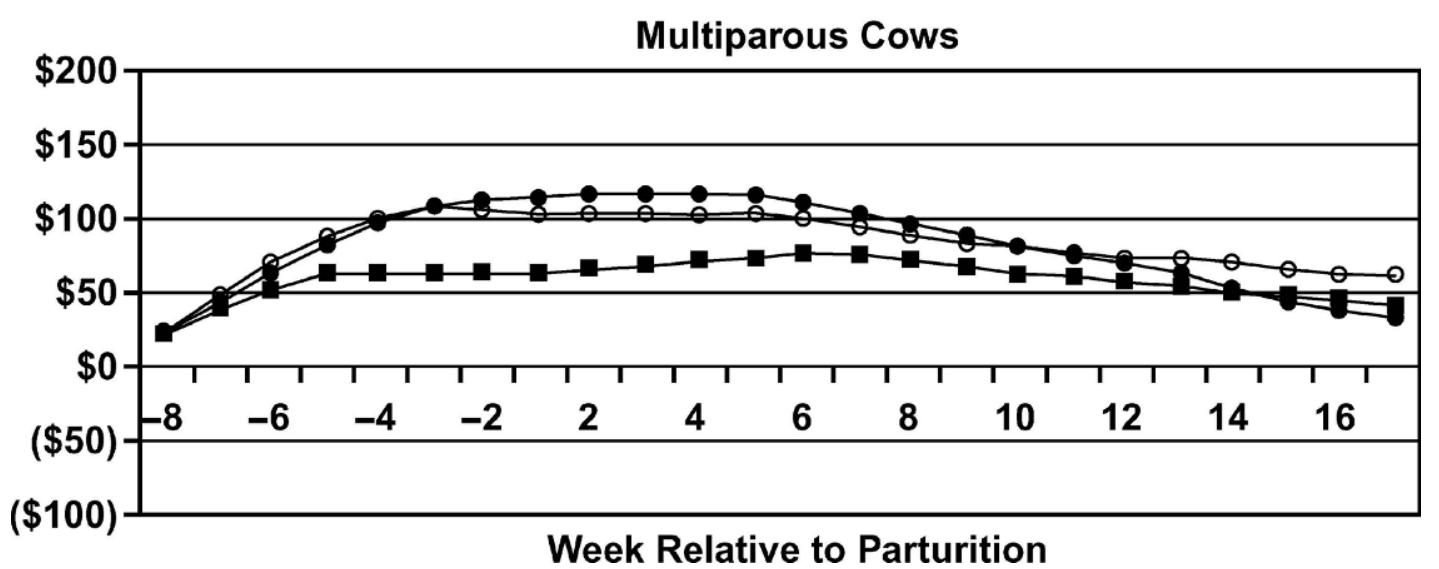

Figure 3. Cumulative net margins (calculated relative to the 60DD group) during late gestation and 17 wk of the next lactation in cows subjected to a shortened or omitted dry period and bST supplementation. $\mathbf{a}=30 \mathrm{DD}$ (30-d dry period, label bST supplementation), CMLST (no dry period, label bST supplementation), and $\bigcirc=$ CMCST(no dry period, continuous bST supplementation).

Management of late gestation, lactating cows proved challenging in 2 areas: 1 ) housing facilities for lactating cows in the final $4 \mathrm{wk}$ of gestation and 2) changes in the appearance and consistency of mammary secretions near parturition (previously discussed). Calving CM cows in lactating pens placed calves in high risk areas (i.e., flush lanes), as well as fresh cows and newborn calves in the care of employees not trained to assist dystocias, to evaluate health status of fresh cows, or to administer colostrum to calves. If CM becomes a management practice, it may be necessary to provide a close-up, lactating pen that 1) provides a comfortable place for cows to calve, 2) is safe for calves, and 3) is located in an area on the dairy that focuses on fresh cow and calf management. Additionally, milking personnel should be able to identify CM cows (color-coded leg bands) and receive training on potential changes in the physical properties and appearance of milk near parturition.

\section{CONCLUSION}

Multiparous cows subjected to a shortened (30DD) or omitted (CMLST and CMCST) dry period achieved subsequent milk yields equal to the conventionally managed cows in the 60DD group. Thus, the 4 or $8 \mathrm{wk}$ of additional prepartum milk income resulted in a CNM of $\$ 40$ to $\$ 60$ per multiparous cow at $17 \mathrm{wk}$ of lactation. Primiparous cows demonstrated a longer dry period requirement, as production losses in the 30DD and CM treatments were significant and CNM values were $\$ 0$ or negative by $17 \mathrm{wk}$ of the next lactation. Further studies on effects of dry period length on mammary cell number, turnover, and functionality are justified and should be conducted with both primiparous and multiparous cows. In addition, larger studies designed to evaluate potential health events and status during the transition period, reproductive variables, and milk and colostrum quality are warranted in cows that are CM or are given a shortened dry period. 


\section{ACKNOWLEDGMENTS}

The authors thank Monsanto Company's Animal Agriculture Business for providing financial support for this experiment. The authors also thank Jared L. Gebauer for assisting with data collection and D. M. Hallford, New Mexico State University, for analyzing colostrum samples.

\section{REFERENCES}

Annen, E. L., R. J. Collier, M. A. McGuire, and J. L. Vicini. Effects of dry period length on milk yield and mammary epithelial cells. J. Dairy Sci. 87(E. Suppl.):E66-E76.

Bachman, K. C. 2002. Milk production of dairy cows treated with estrogen at the onset of a short dry period. J. Dairy Sci. 85:797-803.

Bachman, K. C., and M. L. Schairer. 2003. Invited Review: Bovine studies on optimal lengths of dry periods. J. Dairy Sci. 86:3027-3037.

Bauman, D. E., and R. G. Vernon. 1993. Effects of exogenous bovine somatotropin on lactation. Annu. Rev. Nutr. 13:437-461.

Brandon, M. R., and A. K. Lascelles. 1975. The effect of pre-partum milking on the transfer of immunoglobulin into mammary secretion of cows. Aust. J. Biol. Med. Sci. 53:197-204.

Brandon, M. R., D. L. Watson, and A. K. Lascelles. 1971. The mechanism of transfer of immunoglobulin into mammary secretion of cows. Aust. J. Biol. Med. Sci. 49:613-623.

Capuco, A. V., and R. M. Akers. 1999. Mammary involution in dairy animals. J. Mammary Gland Biol. Neoplasia 4:137-144.

Capuco, A. V., R. M. Akers, and J. J. Smith. 1997. Mammary growth in Holstein cows during the dry period: Quantification of nucleic acids and histology. J. Dairy Sci. 80:477-487.

Capuco, A. V., S. E. Ellis, S. A. Hale, E. Long, R. A. Erdman, X. Zhao, and M. J. Paape. 2003. Lactation persistency: Insights from mammary cell proliferation studies. J. Anim. Sci. 81(Suppl. 3):18-31.

Capuco, A. V., D. L. Wood, R. Baldwin, K. McLeod, and M. J. Paape. 2001. Mammary cell number, proliferation, and apoptosis during a bovine lactation: relation to milk production and effect of bST. J. Dairy Sci. 84:2177-2187.

Coppock, C. E., R. W. Everett, R. P. Natzke, and H. R. Ainslie. 1974. Effect of dry period length on Holstein milk production and selected disorders at parturition. J. Dairy Sci. 57:712-717.

Dias, F. M., and F. R. Allaire. 1982. Dry period to maximize milk production over two consecutive lactations. J. Dairy Sci. 65:136-145.

Duff, G. C., D. A. Walker, K. J. Malcolm-Callis, M. W. Wiseman, and D. M. Hallford. 2000. Effects of pre-shipping vs. arrival medication with tilmicosin phosphate and feed chlortetracycline on health and performance of newly received beef cattle. J. Anim. Sci. 78:267-274.

Fowler, P. A., C. H. Knight, and M. A. Foster. 1991. Omitting the dry period between lactations does not reduce subsequent milk production in goats. J. Dairy Res. 58:13-19.

Funk, D. A., A. E. Freeman, and P. J. Berger. 1987. Effects of previous days open, previous days dry, and present days open on lactation yield. J. Dairy Sci. 70:2366-2373.

Godden, S. M., S. Smith, J. M. Feirtag, L. R. Green, S. J. Wells, and J. P. Fetrow. 2003. Effect of on-farm commercial batch pasteurization of colostrum on colostrum and serum immunoglobulin concentrations in dairy calves. J. Dairy Sci. 86:1503-1512.

Green, M. J., L. E. Green, G. F. Medley, Y. H. Schukken, and A. H. Bradley. 2002. Influence of dry period bacterial intramammary infection on clinical mastitis in dairy cows. J. Dairy Sci. 85:2589-2599.
Gulay, M. S., M. J. Hayen, K. C. Bachman, T. Belloso, M. Liboni, and H. H. Head. 2003. Milk production and feed intake of Holstein cows given short (30-d) or normal (60-d) dry periods. J. Dairy Sci. 86:2030-2038.

Gulay, M. S., M. J. Hayen, M. Liboni, T. I. Belloso, C. J. Wilcox, and H. H. Head. 2004. Low doses of bovine somatotropin during transition period and early lactation improves milk yield, efficiency of production, and other physiological responses of Holstein cows. J. Dairy Sci. 87:948-960.

Guy, M. A., T. B. McFadden, D. C. Cockrell, and T. E. Besser. 1994a. Regulation of colostrum formation in beef and dairy cows. J. Dairy Sci. 77:3002-3007.

Guy, M. A., T. B. McFadden, D. C. Cockrell, and T. E. Besser. 1994b. Effects of unilateral prepartum milking on concentrations of immunoglobulin G1 and prolactin in colostrum. J. Dairy Sci. 77:3584-3591.

Husband, A. J., M. R. Brandon, and A. K. Lascelles. 1972. Absorption and endogenous production of immunoglobulins in calves. Aust. J. Exp. Biol. Med. Sci. 50:491-498.

Klein, J. W., and T. E. Woodward. 1943. Influence of length of dry period upon the quantity of milk produced in the subsequent lactation. J. Dairy Sci. 26:705-713.

Linzell, J. L., and M. Peaker. 1974. Changes in colostrum composition and in the permeability of the mammary epithelium at about the time of parturition in the goat. J. Physiol. 243:129-151.

Lotan, E., and J. H. Alder. 1976. Observations on the effect of shortening the dry period on milk yield, body weight, and circulating glucose and FFA levels in dairy cows. Tijdschr. Diergeneesk. 101:77-82.

Marquis, G. S., M. E. Penny, J. P. Zimmer, J. M. Diaz, and R. M. Marin. 2003. An overlap of breastfeeding during late pregnancy is associated with subsequent changes in colostrum composition and morbidity rates among Peruvian infants and their mothers. J. Nutr. 133:2585-2591.

Maule-Walker, F. M. 1984. Exocrine and endocrine secretions of the mammary gland: Local control in ruminants. Symp. Zool. Soc. Lond. 51:171-191.

Mazzone, M. M., D. W. Holcombe, C. J. Ackerman, C. E. Balok, A. Mendoza-Reyes, and D. M. Hallford. 1999. Effect of short-term protein supplementation on colostrum and ewe and lamb serum immediately after parturition. Sheep and Goat Res. J. 15:64-73.

National Animal Health Monitoring System. 1996. Part 1: Reference of 1996 Dairy Management Practices. USDA Anim. Plant Inspection Serv., Fort Collins, Co.

Paape, M. J., and H. A. Tucker. 1969. Influence of length of dry period on subsequent lactation in the rat. J. Dairy Sci. 52:518-522.

Pitkow, H. S., R. P. Reece, and G. L. Waszilycsak. 1972. The integrity of mammary alveolar cells in two consecutive lactations. Proc. Soc. Exp. Biol. Med. 139:845-850.

Rastani, R. R., R. R. Grummer, S. J. Bertics, A. Gümen, M. C. Wiltbank, D. G. Mashek, and M. C. Rich. 2003. Effects of varying dry period length and prepartum diet on metabolic profiles and lactation of periparturient dairy cattle. J. Dairy Sci. 86:154. (Abstr.)

Rémond, B., J. Kérouanton, and V. Brocard. 1997. Effets de la réduction de la durée de la période séche ou de son omission sur les performances des vaches laitiéras. INRA Prod. Anim. 10:301-333.

Rémond, B., A. Ollier, and G. Miranda. 1992. Milking cows in late pregnancy: Milk production during this period and during the succeeding lactation. J. Dairy Res. 59:233-241.

Richards, J. B., D. M. Hallford, and G. C. Duff. 1999. Serum luteinizing hormone, testosterone, and thyroxine and growth hormone responses of ram lambs fed locoweed (Oxytropis sericea) and treated with vitamin E/selenium. Theriogenology 52:1055-1066.

SAS User's Guide: Statistics, Version 8.0 Edition. 1999. SAS Inst., Inc., Cary, NC.

Schaeffer, L. R., and C. R. Henderson. 1972. Effects of day dry and days open on Holstein milk production. J. Dairy Sci. 55:107-112. 
Smith, K. L., D. A. Todhunter, and P. S. Schoenberger. 1985. Environmental pathogens and intramammary infection during the dry period. J. Dairy Sci. 68:402-417.

Smith, A., J. V. Wheelock, and F. H. Dodd. 1967. Effect of milking throughout pregnancy on milk secretion in the succeeding lactation. J. Dairy Res. 34:145-150.

Sørensen, J. T., and C. Enevoldsen. 1991. Effect of dry period length on milk production in subsequent lactation. J. Dairy Sci. $74: 1277-1283$

Swanson, E. W. 1965. Comparing continuous milking with sixty-day dry periods in successive lactations. J. Dairy Sci. 48:1205-1209.
Swanson, E. W., F. E. Pardue, and D. B. Longmire. 1967. Effect of gestation and dry period on deoxyribonucleic acid and alveolar characteristics of bovine mammary glands. J. Dairy Sci. 50:1288-1292

Wheelock, J. V., J. A. F. Rook, and F. H. Dodd. 1965. The effect of milking throughout the whole pregnancy on the composition of cow's milk. J. Dairy Res. 32:249-254.

Wilton, J. W., E. B. Burnside, and J. C. Rennie. 1967. The effects of days dry and days open on the milk and butterfat production of Holstein Friesian cattle. Can. J. Anim. Sci. 47:85-90. 